\title{
Helminthosporium spiciferum, foliar parasite of rice in Morocco
}

\author{
B Ennaffah, F Bouslim, R Benkirane, A Ouazzani Touhami, A Douira *
}

Laboratoire de botanique, faculté des sciences de Kénitra, Kenitra, Morocco

(Received 6 February; accepted 10 June 1997)

Summary - In this study, the pathogenicity of two isolates of Helminthosporium spiciferum has been examined. All varieties of rice widely cultured in the Gharb were susceptible to this parasite. The foliar lesions are different from those noted on the plants of rice inoculated by $H$ Oryzae.

\section{Oryza sativa $=$ rice $/$ Helminthosporium spiciferum $/$ symptoms}

Résumé - Helminthosporium spiciferum, parasite des feuilles de riz au Maroc. Dans cette étude, le pouvoir pathogène de deux isolats d'Helminthosporium spiciferum a été examiné. Toutes les variétés de riz largement cultivées dans le Gharb se sont montrées sensibles à ce parasite. Les lésions foliaires développées sont différentes de celles notées sur les plantes de riz inoculées avec $H$ oryzae.

Oryza sativa $=$ riz $/$ Helminthosporium spiciferum $/$ symptômes

\section{INTRODUCTION}

The diseases caused by Pyricularia oryzae and Helminthosporium oryzae constitute a major handicap in rice-growing countries. In Morocco, the Helmintosporiums appear among the most predominant fungus species on rice seeds (Benkirane, 1995), and on foliar lesions of rice plants (Benkirane et al, 1994). A parasite (Helminthosporium oryzae, $H$ spiciferum, $H$ australiensis, Curvularia lunata, Fusarium sp, Pyricularia oryzae) can sometimes be isolated from foliar lesions of rice leaf. A knowledge of the pathogenicity of each parasite is, however, necessary to determine a prevention program. The cultural characteristics of $H$ spiciferum have been described by Bouslim (1996), but the pathogenicity on rice has never been reported.

\section{MATERIAL AND METHODS}

\section{Pathogen}

Isolates of $H$ spiciferum were collected from lesions on cultivated rice variety (Elio and Triomphe) and maintained on potato-dextrose agar in the dark at $28^{\circ} \mathrm{C}$. 
Table I. Sensibility or resistance of rice varieties to Helminthosporium spiciferum isolates.

\begin{tabular}{lcccccc}
\hline & \multicolumn{7}{c}{ Variety } \\
\cline { 2 - 6 } Isolate & Triomphe & Samar & 446 & Taibonnet & Plata & Kenz \\
\hline HT & $\mathrm{S}$ & $\mathrm{S}$ & $\mathrm{S}$ & $\mathrm{S}$ & $\mathrm{S}$ & $\mathrm{S}$ \\
$\mathrm{HE}$ & $\mathrm{S}$ & $\mathrm{S}$ & $\mathrm{S}$ & $\mathrm{S}$ & $\mathrm{R}$ & $\mathrm{S}$ \\
\hline
\end{tabular}

\section{Host plants}

Six rice seeds were placed in water-soaked cotton, and were incubated in the dark at $28^{\circ} \mathrm{C} ; 75 \mathrm{~h}$ later, the plants were planted in plastic pots containing soil and watered with tap water until inoculation stage (4 to 6 leaves).

\section{Inoculation}

The inoculum was a conidia suspension $\left(10^{6}\right.$ spore. $\mathrm{moL}^{-1}$ ) obtained by washing 15-day-old fungal colony. The inoculation was carried out by spraying inoculum on the rice leaves with an atomizer. All inoculated plants were enclosed in individual polyethylene bags for $48 \mathrm{~h}$ and placed in a greenhouse.

Disease scoring was based on the scale of Mackill and Bonman (1992) modified in our laboratory to adapt it to the symptom types caused by $H$ spiciferum.

\section{RESULTS}

Table I shows that the rice varieties: Triomphe, Samar, 446, Taibonnet and Kenz are sensitive to $H$ spiciferum and that the Plata variety is resistant to HE isolate of this parasite. The symptoms developed on the rice are different from those caused by $H$ oryzae. The rice cultivars inoculated by $H$ spiciferum present an elongated brown spot, studded with whitish and brownish zones.

These results permit us to identify as $H s p i$ ciferum the dominant parasite of the rice plant. Resistant varieties are the most efficient way to reduce the damage caused by this Helminthosporium.

\section{REFERENCES}

Benkirane R (1995) Contribution à l'étude des maladies du riz au Maroc. Cas de la pyriculariose due à $P$ oryzae. Thèse de docteur de troisième cycle, faculté des sciences de Kénitra, $189 \mathrm{p}$

Benkirane R, Douira A, El Oirdi M, Ouazzani Touhami A, Bouslim F, Karmoussi M, Fadli M, El Halouin E (1994) Study of the fungi flora associated with the rice seed in Morocco. Fifth Arab Congres of Plant Protection, Fes, 27 November 2 December, $47 \mathrm{p}$

Bouslim F (1996) Contribution à l'étude de l'Helminthosporilose du riz au Maroc due à l'Helminthosporium oryzae. Thèse de $3^{\mathrm{e}}$ cycle, faculté des sciences de Kénitra, université Ibn Tofail, $148 \mathrm{p}$

MacKill DJ, Bonman J (1992) Inheritance of blast resistance in near isogenic lines of rice. Phytopathology 82, 746-749 